\title{
ANALISIS PENGARUH PENDINGINAN KACA LUAR ALAT DESALINASI AIR LAUT DOUBLE SLOPE SOLAR STILL
}

\author{
William $^{1 *}$, Himsar Ambarita ${ }^{2}$, Tulus B. Sitorus ${ }^{3}$, Dian M. Nasution ${ }^{4}$, Pramio G. Sembiring ${ }^{5}$ \\ 1,2,3,4,5 Departemen Teknik Mesin, Fakultas Teknik, Universitas Sumatera Utara \\ Email:williamwijayaa98@gmail.com
}

\begin{abstract}
Water plays an essential part in human life. In our daily activities, water is something we must consume for our survival. As one of the largest seawater resources country in the world does not guarantee Indonesian citizens of having pure water to consume. Since, most of the water is already polluted by factories, industries and households. The needs of pure water is increaslingly needed as the human population gradually increased. One of the technology to produce the pure water is solar distillation. This research aims to find out the water productivity results and the efficiency of glass cover cooling by flowing water over the passive double slope solar still glass cover. The results showed that the efficiency increasement by using glass cover cooling technique are $40.39 \%$ and $17.82 \%$ by theory calculation and in actual terms respectively.
\end{abstract}

Keywords: Double Slope Solar Still, Water Distillation, Solar Energy, Cooling Glass Cover

\begin{abstract}
Abstrak
Air mempunyai peranan penting dalam kehidupan manusia. Dalam kehidupan kita sehari-hari air merupakan sesuatu hal yang wajib kita konsumsi untuk keberlangsungan hidup. Sebagai salah satu negara dengan sumber daya air berupa laut terbesar di dunia tidak menjamin warga Indonesia untuk mendapatkan air bersih yang layak untuk dikonsumsi. Hal ini dikarenakan kebanyakan air yang sudah tercemar oleh limbah pabrik, industri dan rumah tangga. Sehingga kebutuhan akan air bersih semakin hari semakin meningkat ditambah dengan bertambahnya populasi manusia. Salah satu teknologi untuk mendapatkan air bersih adalah dengan destilasi tenaga surya. Penelitian ini bertujuan untuk mengetahui hasil produktivitas dan membandingkan efisiensi dari adanya pendinginan kaca luar dengan mengalirkan air dingin pada alat desalinasi air laut sistem pasif dengan kemiringan ganda. Hasil penelitian menunjukkan bahwa peningkatan efisiensi dari penggunaan air dingin sebagai pendinginan kaca luar adalah 40,39\% dan 17,82\% masing-masing secara teoritis dan aktual.
\end{abstract}

Kata Kunci : Alat Desalinasi Air Laut Kemiringan Ganda, Destilasi Air, Energi Surya, Pendinginan Kaca Luar

\section{PENDAHULUAN}

Desalinasi secara luas diadopsi dalam Timur Tengah, Negara Arab, Amerika Utara, Asia, Eropa, Afrika, Amerika Tengah, Amerika Selatan dan Australia untuk memenuhi kebutuhan air bersih dan kebutuhan pengolahan air. Hampir 10000 ton minyak dibutuhkan setiap tahun untuk memproduksi $1000 \mathrm{~m}^{3} /$ hari air bersih. Sistem desalinasi konvensional yang dioperasikan dengan menggunakan bahan bakar fosil juga turut mengkontribusikan emisi rumah kaca atau GHG (Green House Gas). Hal inilah yang mendorong para peneliti untuk mencari cara alternatif untuk memberi daya pada sistem dengan energi terbarukan.

Energi terbarukan yang digunakan oleh proses desalinasi umumnya berupa energi surya, angin, dan geotermal. Diantara ketiganya, 57\% sistem desalinasi disuplai dengan tenaga surya sebagai energi terbarukan. Bahkan negara yang kaya akan bahan bakar fosil seperti Timur Tengah dan Bangsa Arab juga telah mengubah perhatian mereka pada energi surya dengan tujuan dapat menyediakan air bersih tanpa mencemari lingkungan.

\section{TEORI DASAR}

\subsection{Energi Surya}

Matahari merupakan salah satu sumber daya yang dapat diperbarui dengan ketersediaan yang melimpah dengan memancarkan energi radiasinya. Salah satu potensi energi radiasi surya terbanyak dalam sebuah negara adalah Indonesia, dengan lokasi geografis yang terletak di daerah khatulistiwa yang menyebabkan Indonesia beriklim tropis dengan mengalami dua fase 
setiap tahunnya, yakni musim hujan dan musim kemarau. Nilai potensi energi radiasi surya di Indonesia adalah $16 \mathrm{MJ} /$ hari.

Beberapa istilah yang biasanya dijumpai pada perhitungan radiasi adalah:

1. Massa udara $(m)$

$$
m=\frac{1}{\cos \theta_{z}}
$$

Keterangan:

$\mathrm{m}=$ massa udara

$\theta_{\mathrm{z}}=$ sudut zenith

2. Radiasi beam

3. Radiasi difusi

4. Radiasi total

5. Laju radiasi $\left(\mathrm{W} / \mathrm{m}^{2}\right)$

6. Irradiation atau Radian Exposure $\left(\mathrm{J} / \mathrm{m}^{2}\right)$

7. Jam Matahari (Solar Time)

$$
\mathrm{ST}=\mathrm{STD} \pm 4\left(\mathrm{~L}_{\mathrm{st}}-\mathrm{L}_{\mathrm{loc}}\right)+\mathrm{E}
$$

Keterangan:

$\mathrm{ST}=$ jam matahari

STD $=$ jam standard

$\mathrm{L}_{\mathrm{st}}=$ meridian untuk waktu daerah setempat, sementara

$\mathrm{L}_{\mathrm{loc}}=$ derajat bujur daeah yang diukur.

Dimana $E$ adalah persamaan waktu yang dihitung dengan persamaan Spencer, 1981:

$\mathrm{E}=229,2(0,000075+0,00186 \cos \mathrm{B}-0,032077 \sin \mathrm{B}-0,014615 \cos 2 \mathrm{~B}-0,04089 \sin 2 \mathrm{~B})$

(3)

Keterangan:

$\mathrm{E}=$ persamaan waktu

$\mathrm{B}=$ variable hari

Dimana, $B$ diperoleh dengan menggunakan persamaan:

$$
B=(n-1) \frac{360}{365}
$$

Keterangan:

$\mathrm{B}=$ variable hari

$\mathrm{n} \quad=$ nilai urutan hari dalam satu tahun

Nilai sudut deklinasi diperoleh dengan menggunakan persamaan yang diajukkan oleh Cooper (Ambarita, 2011a)

$$
\delta=23,45 \sin \left(360 \frac{(284+\mathrm{n})}{365}\right)
$$

Keterangan:

$\delta=$ sudut deklinasi

$\mathrm{n}=$ nilai urutan hari dalam satu tahun

Atau dapat juga menggunakan persamaan yang lebih teliti, yang diajukan oleh Spencer (Ambarita, 2011a),

$\delta=6,91 \times 10^{-3}-3,99912 \cos \mathrm{B}+0,070251 \sin \mathrm{B}-0,006758 \cos 2 \mathrm{~B}+9,07 \times 10^{-4} \sin 2 \mathrm{~B}-$ $0,002679 \cos 3 \mathrm{~B}+0,00148 \sin 3 \mathrm{~B}$

(6)

Keterangan:

$\delta=$ sudut deklinasi

$B=$ variabel hari

tabel berikut,

Dimana nilai i merupakan nilai urutan hari dalam satu tahun yang dapat diperoleh dari

\begin{tabular}{|c|c|c|}
\hline No. & Bulan & $\begin{array}{c}\text { Nilai n pada } \\
\text { hari ke-i }\end{array}$ \\
\hline 1 & Januari & I \\
\hline 2 & Februari & $31+\mathrm{i}$ \\
\hline
\end{tabular}




\begin{tabular}{|c|c|c|}
\hline 3 & Maret & $59+\mathrm{i}$ \\
\hline 4 & April & $90+\mathrm{i}$ \\
\hline 5 & Mei & $120+\mathrm{i}$ \\
\hline 6 & Juni & $151+\mathrm{i}$ \\
\hline 7 & Juli & $181+\mathrm{i}$ \\
\hline 8 & Agustus & $212+\mathrm{i}$ \\
\hline 9 & September & $243+\mathrm{i}$ \\
\hline 10 & Oktober & $273+\mathrm{i}$ \\
\hline 11 & November & $304+\mathrm{i}$ \\
\hline 12 & Desember & $334+\mathrm{i}$ \\
\hline
\end{tabular}

Sudut jam $\omega$ adalah sudut pergeseran semu matahari dari garis siang.

$$
\omega=15(\mathrm{STD}-12)+(\mathrm{ST}-\mathrm{STD}) \times \frac{15}{60}
$$

Radiasi pada hari ke-n dirumuskan oleh Duffie dan Beckman, 1991.

$\mathrm{G}_{\mathrm{on}}=\mathrm{G}_{\mathrm{sc}}(1,00011+0,034221 \cos \mathrm{B}+0,00128 \sin \mathrm{B}+0,000719 \cos 2 \mathrm{~B}+0,000077 \sin 2 \mathrm{~B})$ (8)

Dimana B dapat diperoleh dengan menggunakan persamaan yang sebelumnya telah diuraikan diatas:

$$
\cos \theta_{z}=\cos \varphi \cos \delta \cos \omega+\sin \varphi \sin \delta
$$

Parameter lain yang digunakan untuk perhitungan radiasi secara teoritis yaitu, estimasi bahwa langit dalam kondisi cerah. Maka dalam hal ini perlu diketahui $\tau_{\mathrm{b}}$,

dimana, nilai masing-masing parameter

$$
\tau_{\mathrm{b}}=\mathrm{a}_{\mathrm{o}}+\mathrm{a}_{1} \exp \left(\frac{-\mathrm{k}}{\cos \theta_{\mathrm{z}}}\right)
$$

Dimana:

$$
\begin{aligned}
& a_{0}=r_{0}\left(0,4237-0,0082(6-A)^{2}\right) \\
& a_{1}=r_{1}\left(0,5055+0,00595(6,5-A)^{2}\right) \\
& k=r_{k}\left(0,2711+0,01858(2,5-A)^{2}\right)
\end{aligned}
$$

$A$ adalah ketinggian $(\mathrm{km})$ dan $r_{o}, r_{l}$, dan $r_{k}$ adalah koreksi akibat iklim.

Nilai faktor koreksi akibat iklim ditampilkan pada tabel

\begin{tabular}{|c|l|l|l|}
\hline Iklim & $\mathrm{r}_{\mathrm{o}}$ & $\mathrm{R}_{1}$ & $\mathrm{r}_{\mathrm{k}}$ \\
\hline Tropical & 0,95 & 0,98 & 1,02 \\
\hline $\begin{array}{c}\text { Midiatude } \\
\text { Summer }\end{array}$ & 0,97 & 0,99 & 1,02 \\
\hline Subartic Summer & 0,99 & 0,99 & 1,01 \\
\hline Midiatude Winter & 1,03 & 1,01 & 1,00 \\
\hline
\end{tabular}

Radiasi beam adalah radiasi matahari yang jatuh langsung ke permukaan bumi,

$$
\mathrm{G}_{\mathrm{beam}}=\mathrm{G}_{\mathrm{on}} \tau_{\mathrm{b}} \cos \theta_{\mathrm{z}}
$$

Radiasi diffuse adalah radiasi hasil pantulan atmosfer.

Maka total radiasi teoritis

$$
\mathrm{G}_{\text {diffuse }}=\mathrm{G}_{\mathrm{on}} \cos \theta_{\mathrm{z}}\left(0,271-0,294 \tau_{\mathrm{b}}\right)
$$

$$
\mathrm{G}_{\text {total }}=\mathrm{G}_{\text {beam }}+\mathrm{G}_{\text {diffuse }}
$$




\subsection{Teori Dasar Desalinasi}

Desalinasi merupakan cara yang efektif digunakan untuk menghasilkan air bersih yang bebas dari kuman, bakteri, dan kotoran yang berupa padatan kecil. Proses desalinasi secara umum biasanya yang diambil hanyalah air kondensatnya, sedangkan konsentrat garam dibuang dan ini dapat berakibat buruk bagi kehidupan air laut. Prinsip kerja desalinasi secara umum sebenarnya sangat sederhana. Air laut dipanaskan hingga menguap, dan kemudian uap yang dihasilkan dikondensasikan kembali dan ditampung di sebuah wadah. Air kondensat tersebut adalah air bersih. Sedangkan air laut yang tidak mendidih selama pemanasan adalah konsentrat garam.

\subsection{Solar Still}

Kelebihan menggunakan Solar Still :

1. Konstruksi yang sederhana,

2. Kondensasi tidak memerlukan kondensor, proses kondensasi terjadi pada kaca.

3. Mudah dalam perawatannya.

Kelemahan menggunakan Solar Still :

1. Laju produksi air bersih per hari rendah.

2. Sebagian uap air yang terkondensasi pada kaca dapat langsung jatuh kembali dan bercampur dengan air laut yang belum berevaporasi.

3. Proses evaporasi lambat karena air laut dipanaskan pada tekanan atmosfer.

\subsection{Double Slope Solar Still (DSSS)}

Jenis penyuling tenaga surya (Solar Still) yang digunakan pada penelitian kali ini adalah Double Slope Solar Still. Bila pada Single Slope kaca yang digunakan hanya kaca tunggal (satu) maka pada Double Slope kaca yang digunakan berjumlah ganda (dua) yang masing-masing menghadap arah timur dan barat.

\subsection{Set-Up Eksperimental}
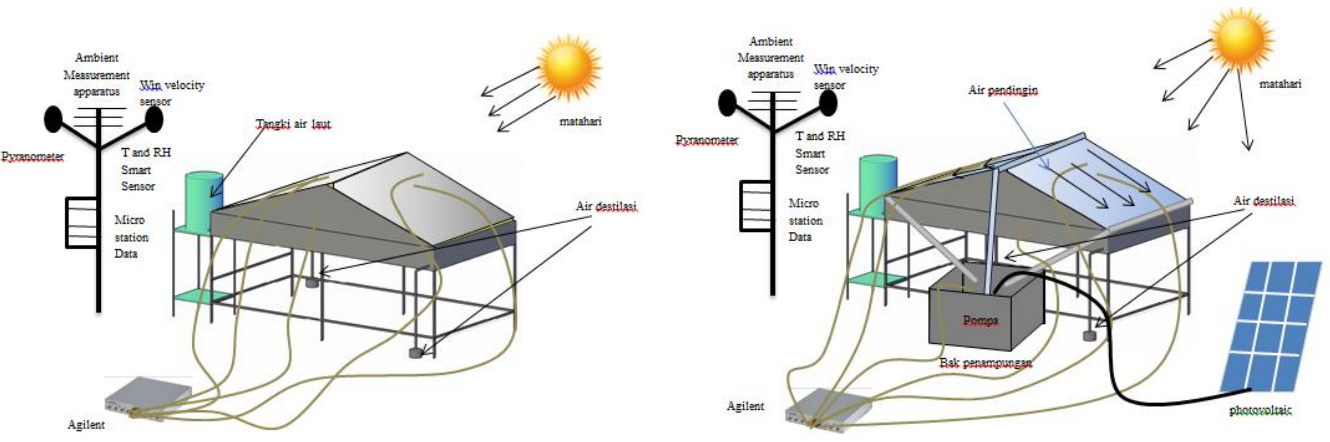

Gambar 2.1 DSSS tanpa pendinginan kaca luar Gambar 2.2 DSSS dengan pendinginan kaca luar

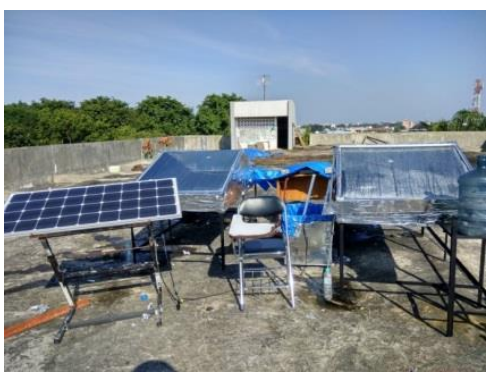

Gambar 2.3 Tampilan keseluruhan alat 
2.6 Parameter Desain dan Spesifikasi Alat

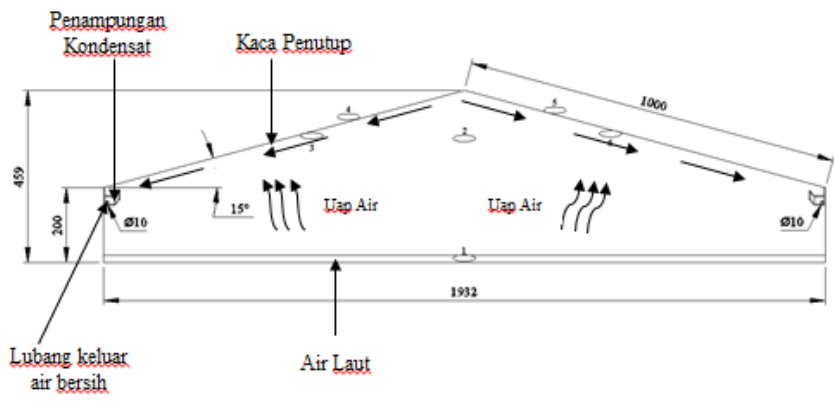

Gambar 2.4 Parameter Desain dan Spesifikasi Alat

Tinggi bawah

Tinggi atas

Panjang evaporator

Lebar evaporator

Tinggi basin dari tanah
: $200 \mathrm{~mm}$

: $459 \mathrm{~mm}$

: $1932 \mathrm{~mm}$

: $1000 \mathrm{~mm}$

\subsection{Analisis pada Double Slope Solar Still}

\section{Perpindahan panas internal}

Perpindahan panas internal terjadi di dalam penyuling matahari dari permukaan air ke permukaan bagian dalam penutup kaca, yang terutama terdiri dari evaporasi, konveksi dan radiasi. Perpindahan panas konvektif dan menguap berlangsung secara bersamaan dan independen dari perpindahan panas radiasi.

a. $\quad$ Perpindahan panas radiasi

Koefisien perpindahan panas radiasi antara air ke kaca diberikan sebagai berikut:

$$
\begin{aligned}
& \mathrm{h}_{\mathrm{rwgE}}=\varepsilon_{\text {eff }} \sigma\left[\left(\mathrm{T}_{\mathrm{w}}+273\right)+\left(\mathrm{T}_{\mathrm{giE}}+273\right)\right]^{2}\left(\mathrm{~T}_{\mathrm{w}}+\mathrm{T}_{\text {giE }}+546\right) \\
& \mathrm{h}_{\mathrm{rwgW}}=\varepsilon_{\mathrm{eff}} \sigma\left[\left(\mathrm{T}_{\mathrm{w}}+273\right)+\left(\mathrm{T}_{\mathrm{giW}}+273\right)\right]^{2}\left(\mathrm{~T}_{\mathrm{w}}+\mathrm{T}_{\mathrm{giW}}+546\right)
\end{aligned}
$$

\section{Dimana,}

$\mathrm{h}_{\mathrm{rwgE}}=$ Koefisien perpindahan panas radiasi dari air ke kaca sisi timur $\left(\mathrm{W} / \mathrm{m}^{2}{ }^{\circ} \mathrm{C}\right)$

$\mathrm{h}_{\mathrm{rwgW}}=$ Koefisien perpindahan panas radiasi dari air ke kaca sisi barat $\left(\mathrm{W} / \mathrm{m}^{2}{ }^{\circ} \mathrm{C}\right)$

$\sigma \quad=$ Koefisien Stephan-Boltzman yaitu $\left(5,67 \times 10^{-8} \mathrm{~W} / \mathrm{m}^{2} \mathrm{~K}^{4}\right)$

$\mathrm{T}_{\mathrm{w}} \quad=$ Suhu air pada di dalam basin $\left({ }^{\circ} \mathrm{C}\right)$

$\mathrm{T}_{\mathrm{giE}} \quad=$ Suhu kaca dalam sisi timur $\left({ }^{\circ} \mathrm{C}\right)$

$\mathrm{T}_{\mathrm{giW}}=$ Suhu kaca dalam sisi barat $\left({ }^{\circ} \mathrm{C}\right)$

Dimana Daya pancar efektif antara air ke kaca penutup disajikan sebagai berikut:

$$
\frac{1}{\varepsilon_{\text {eff }}}=\frac{1}{\varepsilon_{\mathrm{w}}}+\frac{1}{\varepsilon_{\mathrm{g}}}-1
$$

Dimana,

$\varepsilon_{\mathrm{w}}=$ Emisivitas air

$\varepsilon_{\mathrm{g}}=$ Emisivitas kaca 
b. Perpindahan panas konveksi

Konveksi alami terjadi di udara lembab di dalam bak karena perbedaan temperatur antara permukaan air ke permukaan bagian dalam penutup kaca. Koefisien perpindahan panas konvektif diberikan sebagai berikut:

$$
\mathrm{h}_{\mathrm{cwgE}}=0.884\left[\left(\mathrm{~T}_{\mathrm{w}}-\mathrm{T}_{\mathrm{giE}}\right)+\frac{\left(\mathrm{P}_{\mathrm{w}}-\mathrm{P}_{\mathrm{giE}}\right)\left(\mathrm{T}_{\mathrm{w}}+273\right)}{2.689 \times 10^{5}-\mathrm{P}_{\mathrm{w}}}\right]^{1 / 3}
$$

$$
\begin{gathered}
\mathrm{h}_{\mathrm{cwgW}}=0.884\left[\left(\mathrm{~T}_{\mathrm{w}}-\mathrm{T}_{\mathrm{giw}}\right)+\frac{\left(\mathrm{P}_{\mathrm{w}}-\mathrm{P}_{\mathrm{giw}}\right)\left(\mathrm{T}_{\mathrm{w}}+273\right)}{2.689 \times 10^{5}-\mathrm{P}_{\mathrm{w}}}\right]^{1 / 3} \\
\mathrm{P}_{\mathrm{w}}=\exp \left[25.317-\left(\frac{5144}{273+\mathrm{T}_{\mathrm{w}}}\right)\right]
\end{gathered}
$$

$$
\begin{aligned}
& \mathrm{P}_{\mathrm{giE}}=\exp \left[25.317-\left(\frac{5144}{273+\mathrm{T}_{\mathrm{giE}}}\right)\right] \\
& \mathrm{P}_{\mathrm{giW}}=\exp \left[25.317-\left(\frac{5144}{273+\mathrm{T}_{\text {giW }}}\right)\right]
\end{aligned}
$$

Dimana,

$\mathrm{h}_{\mathrm{cwgE}}=$ Koefisien perpindahan panas konveksi dari air ke kaca sisi timur $\left(\mathrm{W} / \mathrm{m}^{2}{ }^{\circ} \mathrm{C}\right)$

$\mathrm{h}_{\mathrm{cwgW}}=$ Koefisien perpindahan panas konveksi dari air ke kaca sisi barat $\left(\mathrm{W} / \mathrm{m}^{2}{ }^{\circ} \mathrm{C}\right)$

$\mathrm{P}_{\mathrm{w}} \quad=$ Tekanan parsial jenuh air $\left(\mathrm{N} / \mathrm{m}^{2}\right)$

$\mathrm{P}_{\text {giE }}=$ Tekanan parsial jenuh kaca di sisi timur $\left(\mathrm{N} / \mathrm{m}^{2}\right)$

$\mathrm{P}_{\text {giW }}=$ Tekanan parsial jenuh kaca di sisi barat $\left(\mathrm{N} / \mathrm{m}^{2}\right)$

c. Perpindahan panas evaporasi

Kinerja solar masih tergantung pada koefisien transfer panas evaporative dan konvektif. Berbagai ilmuwan mengembangkan hubungan matematika untuk mengevaluasi koefisien transfer panas evaporatif dan konvektif. Penguapan berlangsung di dalam penyuling matahari dengan penambahan panas di air melalui radiasi matahari. Koefisien perpindahan panas evaporatif dan laju perpindahan panas evaporatif sebagai berikut:

(27)

$$
\begin{aligned}
& \mathrm{h}_{\text {ewgE }}=0.016273 \mathrm{~h}_{\mathrm{cwgE}}\left(\frac{\mathrm{P}_{\mathrm{w}}-\mathrm{P}_{\text {giE }}}{\mathrm{T}_{\mathrm{w}}-\mathrm{T}_{\text {giE }}}\right) \\
& \mathrm{h}_{\text {ewgW }}=0.016273 \mathrm{~h}_{\mathrm{cwgW}}\left(\frac{\mathrm{P}_{\mathrm{w}}-\mathrm{P}_{\text {giw }}}{\mathrm{T}_{\mathrm{w}}-\mathrm{T}_{\text {giw }}}\right) \\
& \mathrm{q}_{\text {ewgE }}=\mathrm{h}_{\mathrm{ewgE}}\left(\mathrm{T}_{\mathrm{w}}-\mathrm{T}_{\text {giE }}\right) \\
& \mathrm{q}_{\text {ewgW }}=\mathrm{h}_{\mathrm{ewgW}}\left(\mathrm{T}_{\mathrm{w}}-\mathrm{T}_{\text {giW }}\right)
\end{aligned}
$$

Dimana,

$\mathrm{h}_{\mathrm{ewgE}}=$ Koefisien perpindahan panas evaporasi dari air ke kaca sisi timur $\left(\mathrm{W} / \mathrm{m}^{2}{ }^{\circ} \mathrm{C}\right)$

$\mathrm{h}_{\text {ewgW }}=$ Koefisien perpindahan panas evaporasi dari air ke kaca sisi barat $\left(\mathrm{W} / \mathrm{m}^{2}{ }^{\circ} \mathrm{C}\right)$

$\mathrm{q}_{\text {ewgE }}=$ Laju perpindahan panas evaporasi dari air ke kaca sisi timur $\left(\mathrm{W} / \mathrm{m}^{2}\right)$

$\mathrm{q}_{\text {ewgW }}=$ Laju perpindahan panas evaporasi dari air ke kaca sisi barat $\left(\mathrm{W} / \mathrm{m}^{2}\right)$

\section{Perpindahan panas eksternal}

Perpindahan panas eksternal di penyuling matahari terutama diatur oleh proses konveksi dan radiasi, yang independen satu sama lain. Panas hilang dari permukaan luar gelas ke atmosfer melalui konveksi dan radiasi. Temperatur kaca dan atmosfer secara langsung berkaitan dengan kinerja penyuling matahari. Jadi, kerugian atas harus dipertimbangkan untuk analisis kinerja. Temperatur penutup kaca diasumsikan seragam karena ketebalannya yang kecil. Koefisien kehilangan transfer panas kaca total dengan konveksi dan radiasi dari kaca ke ambien: 


$$
h_{1 g}=h_{c g}+h_{r g a E}+h_{\text {rgaw }}
$$

Dimana,

$\mathrm{h}_{1 \mathrm{~g}}=$ Total koefisien perpindahan panas eksternal $\left(\mathrm{W} / \mathrm{m}^{2}{ }^{\circ} \mathrm{C}\right)$

Koefisien perpindahan panas radiasi antara kaca ke atmosfer diberikan sebagai berikut [17], [27]:

$$
\begin{aligned}
& \mathrm{h}_{\text {rgaE }}= \frac{\varepsilon_{\mathrm{g}} \sigma\left[\left(\mathrm{T}_{\mathrm{giE}}+273\right)^{4}-\left(\mathrm{T}_{\text {sky }}+273\right)^{4}\right]}{\mathrm{T}_{\text {goE }}-\mathrm{T}_{\mathrm{a}}} \\
& \mathrm{h}_{\text {rgaW }}= \frac{\varepsilon_{\mathrm{g}} \sigma\left[\left(\mathrm{T}_{\text {giW }}+273\right)^{4}-\left(\mathrm{T}_{\text {sky }}+273\right)^{4}\right]}{\mathrm{T}_{\text {gow }}-\mathrm{T}_{\mathrm{a}}} \\
& \mathrm{T}_{\text {sky }}=\mathrm{T}_{\mathrm{a}}-6
\end{aligned}
$$

Dimana,

$\mathrm{h}_{\mathrm{rgaE}}=$ Koefisien perpindahan panas radiasi dari air kaca sisi timur ke ligkungan $\left(\mathrm{W} / \mathrm{m}^{2}{ }^{\circ} \mathrm{C}\right)$

$\mathrm{h}_{\text {rgaW }}=$ Koefisien perpindahan panas radiasi dari air kaca sisi barat ke ligkungan $\left(\mathrm{W} / \mathrm{m}^{2}{ }^{\circ} \mathrm{C}\right)$

$\mathrm{T}_{\mathrm{a}} \quad=$ Suhu lingkungan $\left({ }^{\circ} \mathrm{C}\right)$

$\mathrm{T}_{\text {sky }} \quad=$ Suhu atmosfer $\left({ }^{\circ} \mathrm{C}\right)$

Koefisien perpindahan panas konveksi antara kaca ke atmosfer diberikan sebagai berikut:

$$
\mathrm{h}_{\mathrm{cg}}=\left(\begin{array}{c}
{[5.7+3.8 \mathrm{v}] ; \mathrm{v} \leq 5 \mathrm{~m} / \mathrm{s}} \\
{\left[6.15 \mathrm{v}^{0.8}\right] ; \mathrm{v}>5 \mathrm{~m} / \mathrm{s}}
\end{array}\right)
$$

Dimana,

$$
\begin{aligned}
& \mathrm{h}_{\mathrm{cg}}=\text { Koefisien perpindahan panas konveksi rata-rata dari kaca ke lingkungan }\left(\mathrm{W} / \mathrm{m}^{2}{ }^{\circ} \mathrm{C}\right) \\
& \mathrm{v}=\operatorname{Kecepatan} \text { angin }(\mathrm{m} / \mathrm{s})
\end{aligned}
$$

\section{Pendinginan kaca luar}

Salah satu cara untuk meningkatkan efisiensi pada DSSS adalah dengan pendinginan kaca luar. Peningkatan efisiensi pengembunan uap air umumnya dilakukan dengan mengalirkan air pada kaca penutup. Dengan pendinginan maka temperatur kaca penutup akan menjadi rendah sehingga uap air dalam alat destilasi lebih mudah mengembun pada kaca penutup. Untuk menentukan koefisien perpindahan panas konveksi dapat digunakan persamaan berikut:

Dimana,

$$
\mathrm{h}_{\mathrm{cgf}}=\frac{\mathrm{k}_{\mathrm{w}}}{\delta}
$$

$\mathrm{h}_{\mathrm{cgf}}=$ Koefisien perpindahan konveksi dari kaca luar ke air pendingin $\left(\mathrm{W} / \mathrm{m}^{2}{ }^{\circ} \mathrm{C}\right)$

$\mathrm{k}_{\mathrm{w}}=$ Konduktivitas termal air $\left(\mathrm{W} / \mathrm{m}^{\circ} \mathrm{C}\right)$

$\delta=$ Ketebalan air $(\mathrm{m})$

4. Laju penguapan massa air

Untuk mencari laju penguapan massa air destilasi dapat digunakan persamaan berikut:

$$
\begin{aligned}
\dot{\mathrm{M}}_{e w} & =\frac{\mathrm{q}_{\mathrm{ew}}}{\mathrm{h}_{\mathrm{fg}}} \\
\mathrm{q}_{\text {ew }} & =\mathrm{q}_{\mathrm{ewgE}}+\mathrm{q}_{\mathrm{ewgW}}
\end{aligned}
$$

Dimana

$\dot{\mathrm{M}}_{\text {ew }}=$ Laju penguapan $\left(\mathrm{Kg} / \mathrm{m}^{2} \mathrm{~s}\right)$

$\mathrm{q}_{e w}=$ Total laju perpindahan panas evaporasi dari air ke kaca $\left(\mathrm{W} / \mathrm{m}^{2}\right)$

\section{Efisiensi DSSS}


Efisiensi energi adalah rasio jumlah energi panas yang digunakan untuk mendapatkan sejumlah air suling tertentu ke energi matahari yang terjadi dalam interval waktu tertentu. Efisiensi dari sistem dapat dicari menggunakan persamaan berikut:

$$
\begin{aligned}
& \eta_{\text {teoritis }}=\frac{m_{d} \text { teoritis } x h f g}{\Sigma I(t) \cdot A t} \times 100 \% \\
& \eta_{\text {aktual }}=\frac{m_{d} \text { aktual } \times h f g}{\Sigma I(t) \cdot A t} \times 100 \%
\end{aligned}
$$

6. Hasil distilasi

Output distilasi per 30 menit dari unit penyuling tenaga surya dapat diperoleh sebagai berikut:

$$
\begin{aligned}
& \mathrm{m}_{\mathrm{ewE}}=\frac{\mathrm{q}_{\mathrm{ewgE}} \cdot \mathrm{A}_{\mathrm{b} .1800}}{\mathrm{~h}_{\mathrm{fg}}} \\
& \mathrm{m}_{\mathrm{ewW}}=\frac{\mathrm{q}_{\mathrm{ewgW}} \cdot \mathrm{A}_{\mathrm{b} .1800}}{\mathrm{~h}_{\mathrm{fg}}} \\
& \mathrm{m}_{\mathrm{ew}}=\mathrm{m}_{\mathrm{ewE}}+\mathrm{m}_{\mathrm{ewW}}
\end{aligned}
$$

Dimana $\mathrm{h}_{\mathrm{fg}}$ adalah panas laten penguapan dalam $\mathrm{J} / \mathrm{kg}$ dan diberikan oleh persamaan:

$$
\mathrm{h}_{\mathrm{fg}}=3044205,5-1679,1109 \mathrm{~T}_{\mathrm{w}}-1,14258 \mathrm{~T}_{\mathrm{w}}{ }^{2}
$$

\section{HASIL DAN PEMBAHASAN}

Data hasil pengujian yang digunakan pada penelitian ini adalah data suhu pada alat 1 (DSSS tanpa pendinginan kaca luar) dan alat 2 (DSSS dengan pendinginan kaca luar) yang dilakukan pada tanggal 27 Juni 2019 dengan menggunakan alat ukur Agilent yang mengukur dan merekam suhu mulai pukul 08.00 WIB sampai dengan 18.00 WIB. Berikut adalah data suhu pada masingmasing alat yang didapat saat pengujian.

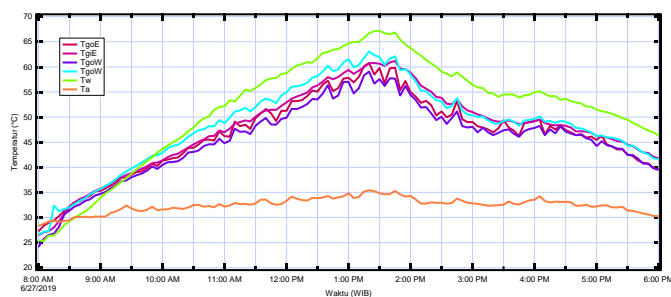

Gambar 4.1 Grafik suhu pada alat 1 vs waktu

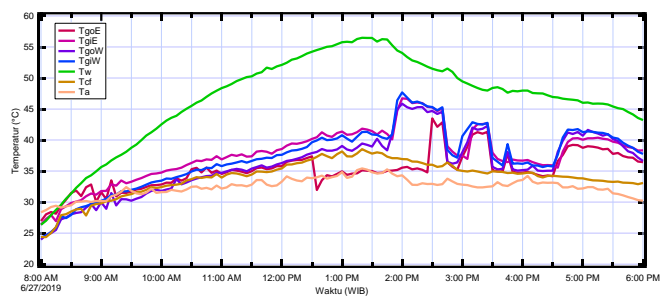

Gambar 4.2 Grafik suhu pada alat 2 vs waktu

Pengujian dimulai pukul 08:00 WIB pada intensitas awal 68,1 W/m² dan berakhir pukul 18:00 WIB dengan intensitas akhir $16,9 \mathrm{~W} / \mathrm{m}^{2}$. Berdasarkan gambar 4.3 , terlihat bahwa radiasi tertinggi pada saat pengujian yaitu sebesar $639,4 \mathrm{~W} / \mathrm{m}^{2}$ yang terjadi pada pukul 13:17 WIB. Total radiasi pengukuran dari pukul 08.00 WIB sampai $18.00 \mathrm{WIB}$ adalah $212424,9 \mathrm{~W} / \mathrm{m}^{2}$. Dengan radiasi rata-rata sebesar $353.45 \mathrm{~W} / \mathrm{m}^{2}$.

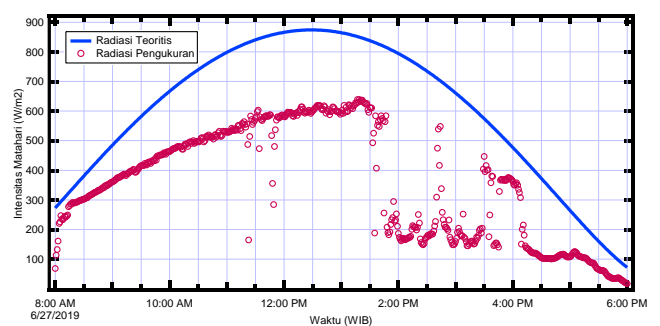

Gambar 4.3 Grafik perbandingan intensitas matahari secara teori dengan radiasi pengukuran

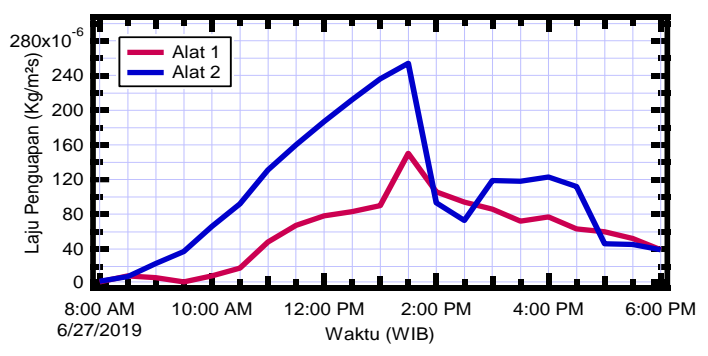

Gambar 4.4 Grafik perbandingan laju penguapan air pada alat 1 dan laju penguapan air pada alat 2 
Berdasarkan gambar 4.4 laju penguapan tertinggi dan terendah pada alat 1 adalah 0,000150 $\mathrm{kg} / \mathrm{m}^{2} \mathrm{~s}$ dan $0,000002 \mathrm{~kg} / \mathrm{m}^{2} \mathrm{~s}$ masing-masing pada pukul $13.30 \mathrm{WIB}$ dan 08.00 WIB. Sementara laju penguapan tertinggi dan terendah pada alat 2 adalah $0,000254 \mathrm{~kg} / \mathrm{m}^{2} \mathrm{~s}$ dan $0,000003 \mathrm{~kg} / \mathrm{m}^{2} \mathrm{~s}$ masing-masing pada pukul 13.00 WIB dan 08.00 WIB. Untuk laju penguapan rata-rata pada alat 1 adalah $0,000058 \mathrm{~kg} / \mathrm{m}^{2} \mathrm{~s}$ sementara laju penguapan rata-rata pada alat 2 adalah 0,000104 $\mathrm{kg} / \mathrm{m}^{2} \mathrm{~s}$

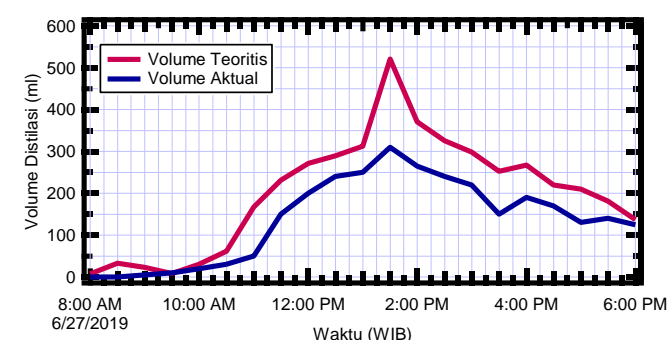

Gambar 4.5 Grafik perbandingan volume distilasi teoritis dengan volume distilasi aktual pada alat 1

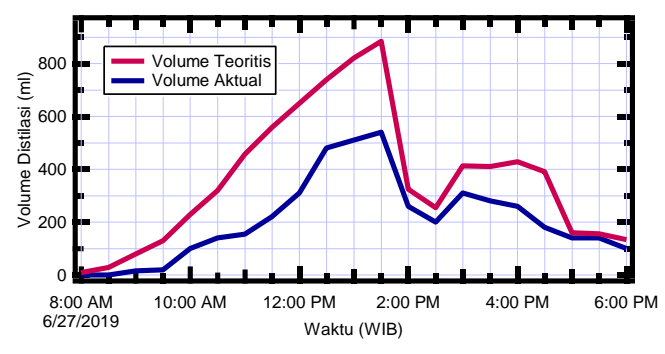

Gambar 4.6 Grafik perbandingan volume distilasi teoritis dengan volume distilasi aktual pada alat 2

Berdasarkan gambar 4.5 volume destilasi teoritis tertinggi dan terendah pada alat 1 adalah 520,24 ml dan 7,66 ml pada pukul 13.30 WIB dan 08.00 WIB. Pada pukul 18.00 WIB secara teoritis volume yang dihasilkan adalah 136,62 ml. Sedangkan volume destilasi aktual tertinggi dan terendah pada alat 1 adalah $310 \mathrm{ml}$ dan $5 \mathrm{ml}$ pada pukul 13.30 WIB dan 09.00 WIB. Pada pukul 08.00 sampai 08.30 tidak ada volume destilasi yang dihasilkan pada alat 1. Sedangkan pada pukul 18.00 WIB volume destilasi aktual yang dihasilkan adalah $125 \mathrm{ml}$. Total volume destilasi secara teoritis pada alat 1 yang dihasilkan adalah 4,216 liter sedangkan total volume destilasi secara aktual pada alat 1 yang didapat adalah 2,895 liter. Pada gambar 4.6, volume destilasi teoritis tertinggi dan terendah pada alat 2 adalah $884,130 \mathrm{ml}$ dan $8,77 \mathrm{ml}$ pada pukul 13.30 WIB dan 08.00 WIB. Pada pukul 18.00 WIB secara teoritis volume yang dihasilkan adalah $134 \mathrm{ml}$. Sedangkan volume destilasi aktual tertinggi dan terendah pada alat 2 adalah 540 dan $15 \mathrm{ml}$ pada pukul 13.30 WIB dan 09.00 WIB. Pada pukul 08.00 sampai 08.30 tidak ada volume destilasi aktual yang dihasilkan pada alat 2. Sedangkan pada pukul 18.00 WIB volume destilasi aktual yang dihasilkan adalah $100 \mathrm{ml}$. Total volume destilasi secara teoritis pada alat 2 yang dihasilkan adalah 7,57 liter sedangkan total volume destilasi secara aktual pada alat 2 yang didapat adalah 4,36 liter.

Terdapat peningkatan produktivitas air bersih dari adanya DSSS dengan pendinginan kaca luar terhadap yang tidak berpendingin. Perbandingan produktivitas air aktual keduanya dapat dilihat pada gambar 4.7 berikut.

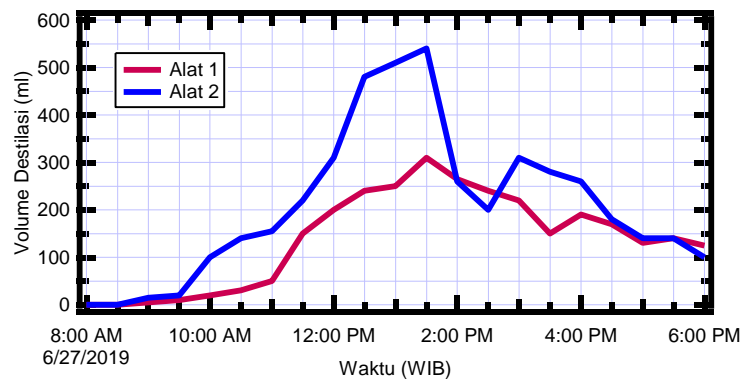


Gambar 4.7 Grafik perbandingan volume distilasi aktual alat 1 dengan volume distilasi aktual pada alat 2

\section{KESIMPULAN DAN SARAN}

\subsection{Kesimpulan}

1. Berdasarkan pengujian yang telah dilakukan, laju penguapan tertinggi dan terendah pada alat 1 adalah $0,000150 \mathrm{~kg} / \mathrm{m}^{2} \mathrm{~s}$ dan $0,000002 \mathrm{~kg} / \mathrm{m}^{2} \mathrm{~s}$ masing-masing pada pukul $13.30 \mathrm{WIB}$ dan 08.00 WIB. Sementara laju penguapan tertinggi dan terendah pada alat 2 adalah $0,000254 \mathrm{~kg} / \mathrm{m}^{2} \mathrm{~s}$ dan $0,000003 \mathrm{~kg} / \mathrm{m}^{2} \mathrm{~s}$ masing-masing pada pukul $13.00 \mathrm{WIB}$ dan 08.00 WIB. Untuk laju penguapan rata-rata pada alat 1 adalah $0,000058 \mathrm{~kg} / \mathrm{m}^{2} \mathrm{~s}$ sementara laju penguapan rata-rata pada alat 2 adalah $0,000104 \mathrm{~kg} / \mathrm{m}^{2} \mathrm{~s}$.

2. Total volume destilasi secara teoritis pada alat 1 yang dihasilkan adalah 4,216 liter sedangkan total volume destilasi secara aktual pada alat 1 yang didapat adalah 2,895 liter. Pada alat 2 volume destilasi secara teoritis yang dihasilkan adalah 7,57 liter, sedangkan total volume destilasi secara aktual pada alat 2 yang didapat adalah 4,36 liter.

3. Efisiensi pada alat 1 secara teoritis didapat sebesar 50,49 dimana secara aktual didapat $34,5 \%$. Efisiensi pada alat 2 secara teoritis didapat sebesar 90,88\% dimana secara aktual didapat $52,32 \%$. Penambahan pendinginan terhadap kaca luar menggunakan air secara teoritis meningkatkan efisiensi sebanyak $40,39 \%$ sementara secara aktual peningkatan efisiensinya sebesar $17,82 \%$.

\subsection{Saran}

1. Pompa langsung terhubung dengan photovoltaic dan tidak adanya penggunaan baterai pada pengujian ini. Sehingga ketika intensitas matahari rendah pompa tidak beropeasi yang menyebabkan air pendinginan yang mengalir sempat terhenti beberapa saat Agar air pendinginan pada kaca luar tetap mengalir stabil maka dibutuhkan penggunaan baterai untuk peneliti selanjutnya.

2. Untuk mengetahui pengaruh pendinginan kaca luar dengan menggunakan air lebih lanjut, perlu dilakukan penelitian dengan kecepatan aliran yang bervariasi.

3. Diperlukan kabel thermocouple yang baru guna meningkatkan ketelitian pengumpulan data ketika pengujian berlangsung serta meminimalisir tingkat error saat pengujian dan perekaman data

4. Isolasi pada sisi-sisi kolektor hendaknya ditingkatkan agar kehilangan panas yang terjadi lebih sedikit sehingga dapat meningkatkan efisiensi sistem.

\section{REFERENSI}

Ambarita, Himsar. 2011a. Energi Surya. Medan: Departemen Teknik Mesin FT USU.

Ambarita, Himsar. 2011b. Perpindahan Panas Konveksi dan Pangantar Alat Penukar Kalor. Medan: Departemen Teknik Mesin FT USU.

Anil Kumar, Om Prakash. 2019. Solar Desalination Technology. Singapore: Springer

Astawa, Ketut, dkk.2011. Jurnal Ilmiah Analisis Performansi Destilasi Air Laut Tenaga Surya Menggunakan Penyerapan Radiasi Surya Tipe Bergelombang Berbahan Dasar Beton. Bali : Universitas Udayana

Eltawil, M.A dkk. 2009. A Review of Renewable Technologies Integrated with Desalination Systems. Renewable Sustainable Energy Reviews Vol.13 Hal. 2245-2262. 
G.N Tiwari, A.Tiwari, Shyam. 2016. Handbook of Solar Energy Theory, Analysis and Applications. Singapore: Springer

Holman, J. 1988. Perpindahan Kalor. Edisi ke-6. Jakarta: Penerbit Erlangga.

Incropera, F. P., and Dewitt. D. P.. 1196. Fundamentals of Heat and Mass Transfer. Fourth Edition. John Wiley \& Sons. New York.

Kalogirou S. Seawater Desalination Using Renewable Energy Sources. Prog Energy.Combust Sci 2005;31:242-81.

Pasaribu, Henri. 2017. Studi Eksperimental Optimasi Solar Water Heater Sistem Hybrid dengan Kapasitas 120 L Air. Medan: Departemen Teknik USU.

P.Doddy, K.Wibowo, F.A.S.Rusdi. (2017, Desember). Pemodelan dan Analisis

Termaldestilasi Air Energi Surya dengan Kaca Penutup Berpenampung Air. Media

Teknika Jurnal Teknologi, 12(2), 1-11.

Pratama, Fransiskus X.R.F. 2015. Destilator Air Energi Termal Surya Jenis Konvensional Menggunakan Pendingin Air Dengan Kaca Ganda. Yogyakarta: Jurusan Teknik Mesin Universitas Sanata Dharma

Qiblawey HM, Banat F. Solar Thermal Desalination Technologies. Desalination 2008;220:63344.

Sharma, V.B. and S.C. Mullick, 1993. Solar Engineering. Trans. ASME, J. 155.P.231.

Yunus, A. Cengel. 2002. Heat Transfer A Practical Approach. Second Edition. MC Graw Hill, Book Company, Inc: Singapore. 